\title{
Há cinquenta anos a Operação Pan-Americana
}

ANTÔNIO CARLOS LESSA*

A Operação Pan-Americana - OPA é uma das iniciativas da diplomacia brasileira que podem ser consideradas fundamentais para a compreensão das inflexôes da ação internacional do Brasil e do processo de amadurecimento e ampliação dos horizontes da sua visão de mundo.

$\mathrm{Na}$ carta que dirigiu ao Presidente Dwight Eisenhower dos Estados Unidos em maio de 1958, o Presidente Juscelino Kubitschek indicava a necessidade de revisão urgente das relações interamericanas, o que fez a partir da percepção de crescimento do sentimento anti-norte-americano nos países da América Latina e de ampla insatisfação com as linhas de cooperação para o desenvolvimento tocadas pelos Estados Unidos. A demonstração de que existia íntima conexão entre desenvolvimento econômico e as condições da segurança hemisférica introjetou na política externa do Brasil uma das idéias-força mais preciosas do pensamento diplomático brasileiro: a de que existe relação necessária entre os níveis de desenvolvimento econômico e as condições de estabilidade sistêmica, seja na América Latina ou em qualquer outra região do mundo. Afinal, o único modo de conter a penetração do comunismo (ou como se afirmava à época, de afastar o risco de contágio das ideologias estranhas à América Latina) seria justamente afastar as suas populaçōes da miséria, promovendo-se o desenvolvimento econômico. Esta tese seria depois apropriada pelo ideário da Política Externa Independente em 1961 e, a partir daí, defendida com vigor pela diplomacia brasileira.

Ainda que os resultados concretos e diretos da OPA sejam considerados limitados, a iniciativa ganha vulto quando são examinadas as suas vinculaçóes com o sentido geral da ação internacional do Brasil naquele momento e dali por diante. Assim, a reivindicação de um novo lugar para o país na política hemisférica e internacional, a busca de reconhecimento do seu amadurecimento político, uma nova construção de autonomia nas suas relaçôes com os Estados Unidos e a valorização do multilateralismo como vetor da ação internacional fazem parte do legado da Operação Pan-Americana.

A Revista Brasileira de Política Internacional é contemporânea da OPA e se fez veículo da crítica social e do debate político sobre a iniciativa. Selecionamos

\footnotetext{
* Editor da Revista Brasileira de Política Internacional - RBPI, professor do Instituto de Relações Internacionais da Universidade de Brasília - UnB e pesquisador do Conselho Nacional de Desenvolvimento Científico e Tecnológico - CNPq (alessa@unb.br)
} 
pequeno conjunto de manifestações publicadas na revista nos seus números iniciais que analisam e documentam as origens, a evolução e evidenciam os limites da Operação.

Ainda em 1958 a Revista publicou um alentado dossiê de síntese sobre a OPA, compilando peças fundamentais para a compreensão dos fundamentos da iniciativa. Dizia a apresentação desse dossiê: "para documentação do desenvolvimento da Operação Pan-Americana publicamos a seguir: a) a Exposição feita as classes armadas pelo Presidente Juscelino Kubitschek, em reunião realizada a 17 de agosto, no Palácio Itamarati; b) notícia do debate de que a Operação PanAmericana foi objeto na Câmara dos Deputados: c) a Nota e o Aide-Mémoire transmitidos pelo Ministério das Relações Exteriores do Brasil aos Governos das Repúblicas Americanas: d) o Comunicado Conjunto da Reunião dos Ministros das Relações Exteriores. expedido em Washington. a 24 de setembro: e) declaração do Ministro Negrão de Lima. divulgada a 19 de outubro. Ainda na presente Resenha publicamos: a) os discursos pronunciados por ocasiāo da visita do Secretário de Estado dos Estados Unidos da América: b) a conferência pronunciada em Assunção pelo Ministro Negrão de Lima: c) a correspondência trocada entre os Presidentes Juscelino Kubitschek e Alberto Lleras Camargo. ${ }^{1}$

No ano seguinte Barreto Leite Filho apresentou um apanhado do estado das negociaçóes em andamento, que era acompanhado de um novo conjunto de documentos produzidos pela chancelaria brasileira ${ }^{2}$. No número 7 , também de 1959, João Carlos Muniz ensaiava sobre o significado da Operação para a ação internacional do Brasil, seguido de nova compilação de documentos ${ }^{3}$.

O volume 3 da RBPI, publicado em 1960, traz em três dos seus quatro números, avaliações preciosas sobre a iniiciativa: Celso A. de Souza e Silva apresentou os antecedentes e os rumos que a iniciativa poderia tomar e publicou-se nova compilação de documentos sobre a Operação ${ }^{4}$. No número 10 da RBPI, publicado em junho daquele ano, José Garrido Torres examinou com circunspecção o sentido geral da iniciativa: "Assim a OPA permanece um propósito, uma expressão de sentimento, um estado de espírito, uma declaração de intenções, um convite aceito, em princípio, por todos os governos americanos para uma ação conjunta que não está planejada em termos de execução metódica, multiforme mas coordenada. Ainda não é uma política; é um diagnóstico. Aguarda um roteiro; não se lhe deu conteúdo programático. Corre o risco, portanto, de

\footnotetext{
1 RBPI. Resenha-A Operação Pan-Americana. Rev. bras. polit. int., Vol. 1, No. 4, dez. 1958, p. 100-128.

2 BARRETO LEITE FILHO. OPA, primeiro ano de discussōes e negociações. Rev. bras. polit. int., Vol. 2, No. 5, mar. 1959, p. 44-77.

3 MUNIZ, João Carlos. Significado da Operação Pan-Americana. Rev. bras. polit. int., Vol. 2, No. 7, set. 1959, p. 5-23; RBPI. Resenha - Comissão dos 21 - Reunião de Buenos Aires. Rev. bras. polit. int., Vol. 2, No. 7 , set. 1959, p. 76-106.

4 SILVA, Celso de A. Souza e. Operação Pan-Americana: antecedentes e perspectivas. Rev. bras. polit. int., Vol. 3, No. 9, mar. 1960, p. 41-59; RBPI. Resenha - A Operação Pan-Americana. Rev. bras. polit. int., Vol. 3, No. 9, mar. 1960, p. 113-139.
} 
confirmar a regra das manifestaçôes líricas em matéria de cooperação econômica no hemisfério. Poderá dissipar-se por falta de consistência" ${ }^{\text {. }}$.

O número 11 da revista, publicado em setembro de 1960 traz nova avaliação de síntese da OPA, publicada na forma de uma resenha, e com ela o editor da revista assume o empenho em atualizar o leitor sobre o desenvolvimento da iniciativa, como se vê em nova resenha publicada no número seguinte ${ }^{6}$.

A série de análises e de avaliaçōes feitas por contemporâneos da iniciativa se encerra em 1961 com o artigo de T. Graydon Upton, ao tempo em que o debate social arrefece e os resultados diretos da OPA já se anunciam limitados: "a interpretação apresentada aqui não sugere, em nenhum momento, a substituição de dólares para o desenvolvimento por estandartes. A 'Operação Pan-Americana' somente poderá ser concretizada se o Governo norte-americano, plenamente apoiado pelo Congresso, envidar o máximo dos seus esforços nos setores econômicos e financeiros, tanto para aumentar como para tornar mais efetiva a assistência de desenvolvimento econômico e social. Mas nem só de pão vive o homem. Quando o esforço máximo econômico e social estiver sendo envidado, não deve atingir apenas as necessidades do homem, porém mentes ágeis e espíritos alevantados. Se se quiser travar uma guerra bem sucedida contra o subdesenvolvimento na América Latina, deve-se ter a escudá-la, para pessoas sensíveis, emocionais e de objetivos elevados, a dedicação de uma grande causa, pois somente dentro do espírito de tal dedicação pode o esforço e o sacrifício individuais serem suscitados, essenciais que são ao bom êxito contra tais desigualdades"7.

Os ideais da OPA deitaram raízes profundas na política externa brasileira e compõem parte das suas tradições, como as conhecemos hoje. Passados cinqüenta anos do seu lançamento é tempo de examinar com novo interesse os seus resultados e a sua importância, como foi feito pela Revista Brasileira de Política Internacional nos seus primeiros dias.

5 TORRES, José Garrido. Operação Pan-Americana, uma política a formular. Rev. bras. polit. int., Vol. 3 , No. 10, Jun. 1960, p. 33-50.

6 RBPI. Resenha - Operação Pan-Americana. Rev. bras. polit. int., Vol. 3, No. 11, set. 1960; RBPI. Resenha - Operação Pan-Americana: Comissão dos 21 - Conferência de Bogotá. Rev. bras. polit. int., Vol. 3, No. 12, dez. 1960.

7 UPTON, Y. T. Graydon. Operação Pan-Americana: o catalizador oculto? Rev. bras. polit. int., Vol. 4, No. 14, Jun. 1961, p. 58-69. 